\title{
$-O$ \\ The Political Origin of Pension Funding
}

Enrico Perotti 1,2

Armin Schwienbacherl,3

' Universiteit van Amsterdam,

2 Tinbergen Institute;

${ }^{3}$ Catholic University of Louvain. 


\section{Tinbergen Institute}

The Tinbergen Institute is the institute for economic research of the Erasmus Universiteit Rotterdam, Universiteit van Amsterdam, and Vrije Universiteit Amsterdam.

Tinbergen Institute Amsterdam

Roetersstraat 31

1018 WB Amsterdam

The Netherlands

Tel.: $\quad+31(0) 205513500$

Fax: $\quad+31(0) 205513555$

Tinbergen Institute Rotterdam

Burg. Oudlaan 50

3062 PA Rotterdam

The Netherlands

Tel.: $\quad+31(0) 104088900$

Fax: $\quad+31(0) 104089031$

Most TI discussion papers can be downloaded at http:/ /www.tinbergen.nl. 


\title{
The Political Origin of Pension Funding
}

\author{
Enrico Perotti \\ University of Amsterdam, NETSPAR and CEPR \\ Armin Schwienbacher \\ University of Amsterdam and Catholic University of Louvain
}

\begin{abstract}
*
This paper argues that historical political preferences on the role of capital markets shaped national choices on pension reliance on private funding.

Under democratic voting, a majority will support investor protection and a privately funded pension system when the middle class has significant financial participation, while high wealth concentration favors a state-funded retirement system and weak investor rights. We present evidence that pension funding is well explained by wealth distribution shocks in the first half of the XX century. The effect is very significant: a large shock reduces the stock of private retirement assets by $58 \%$ of GDP. The results stand after controlling for complementary explanations, such as legal origin, past and current demographics, religion, electoral voting rules, national experiences with financial market performance, or other major financial shocks that were not specifically redistributive.
\end{abstract}

Date: 20 December 2006

\footnotetext{
* We thank Randall Morck, Fabio Braggion, audiences at the University of Amsterdam, Paris School of Economics, the 2006 CEPR Annual Conference on Public Economics (Kiel), the "Workshop on LongTerm Perspectives on Institutions, Business and Finance" (Antwerp), and the "Workshop on the Politics of Corporate Governance" (Copenhagen) for useful comments. We retain responsibility for any errors.
} 


\section{Introduction}

Few issues are as controversial at present as the issue of pension funding. Increased longevity and declining birth rate have affected the ability of pension systems to cover pension liabilities. The debate on pension reform is particularly intense in countries which historically chose to establish a pay-as-you-go system, where it is an open question how the financial consequences of the large projected shortfalls should be distributed across social groups. It appears therefore important to understand the determinants of the original choice on pension funding structure.

The earliest pension plans, starting in Germany in the 1880, were funded, and most worker pensions remained privately invested for decades (although governments granted state pensions to civil servant and war veterans). Current retirement systems in developed countries were adopted soon after the Second World War, and vary considerably on their reliance on a state guarantee, versus private funding on capital markets. While most systems share both features (even the US has a significant Social Security component), private funding across OECD countries varies by far more than the development of their capital markets.

When was the government entrusted with most retirement liabilities in some countries, while elsewhere private funding was preferred? Cutler and Johnson (2004) find hardly any explanatory variable for the timing of adoption of state pension systems, besides income and ethnic fractionalization. Some differences across similar countries are particularly surprising. Why does Finland have so little pension assets in comparison to Denmark or Sweden? Why does Belgium have so little pre-funding in comparison to the Netherlands, or Switzerland so much in comparison to Austria ? ${ }^{1}$

This paper argues that pension funding choices after the Second World War reflected national political preferences on financial markets shaped by the experience of the middle class during the tumultuous interwar period. Moreover, this historical choice

\footnotetext{
${ }^{1}$ Of course, unfunded pension systems (PAYG) have some notional funding, as state pension institutions receive specifically issued public debt. Clearly, these assets exist only on paper, as they are backed by fiscal revenues just as any government liability.
} 
had a self-reinforcing effect, as voters support investor protection only to the extent that they hold security claims on the private sector. ${ }^{2}$

The political economy literature on capital market orientation shows that when the middle class has a high degree of financial participation, it supports minority investor protection, which in turn ensures better financial returns and more financial development. In contrast, in a country where wealth is very concentrated, the middle class relies mostly on labor income. In this case, a political majority will favor high labor rents and weaker investor protection (Pagano and Volpin, 2005; Perotti and von Thadden, 2006), which reduces financial development (La Porta et al, 1997, 1998). As a result, the middle class eschews capital market to fund pensions and seeks a state guarantee. This approach implies that historical wealth inequality has a persistent effect on both capital market development and pension funding.

Testing the political economy explanation directly requires historical measures of wealth distribution, for which hardly any reliable historical data is available. In this paper we adopt a proxy measure suggested in Perotti and von Thadden (2006), namely the dramatic inflationary shocks that hit some countries in the interwar period and caused major wealth losses. Their model suggests that such shocks may explain major financial shifts, identified by Rajan and Zingales (2003) as the Great Reversal. As a result of the loss of their savings, the middle class came to depend more on its labor income and sought more social insurance, in particular after the Great Depression. This shifted political support away from capital markets and in favor of corporatist policies, favoring stability over profitability, in order to limit uninsurable labor income risk (Perotti and von Thadden, 2006). ${ }^{3}$ Subsequent enforcement and regulatory choices weakened control rights for minority investors, granting control to banks, the state and large, undiversified shareholders and reducing significantly the attractiveness of security investments. Inevitably, these political preferences affected the subsequent decision on pension funding. In contrast, countries where the middle class had managed to keep its savings, it maintained its support for investor protection, and chose for market funding.

\footnotetext{
${ }^{2}$ Pagano and Volpin (2006) model this process, and show evidence of a virtuous cycle in equity issuance in recent years, confirmed by an increasing acceptance of foreign takeovers.

${ }^{3}$ Pagano and Volpin (2005) offer evidence about a negative correlation between labor and investor protection.
} 
We test this political economy view by regressing private pension assets in a sample of democracies against these shocks, along with complementary and competing explanations. The results indicate a strong economic and statistic effect of wealth shifts. In particular, a single episode of very high inflation reduces the stock of current private retirement assets by $58 \%$ of GDP. The result is robust to controls for causes related to historical and current demographics, formal political institutioms such as electoral voting rules, religion, legal origin or other independent determinants of financial development, and the national experience with average inflation and financial returns.

This paper relates to the growing literature on pension programs and their sustainability. The political economy of pension systems have been examined, among others, by Conesa and Krueger (1999), and Cooley and Soares (1999). The development of social security programs has wide-spread around the world in early $20^{\text {th }}$ century as a result of demographic and democratic changes as well as urbanization (Lindert, 1994, Caucutt et al., 2006). Lindert (1994) finds that changes in income growth had little impact on the rise of social security spending. While public spending on pensions did not exceed 1\% of GDP for most developed countries, in 2001 public spending on old age benefits amounted to $7.6 \%$ on average in the OECD countries. Overall, the rise in social spending and pension programs has a large component which appear exogenous to political orientations. Typically, these studies focus on pension funding through social security. We seek to contribute by identifying the determinants of the relative share of private to state pension funding.

The paper is structured as follows. The next section sketches our hypotheses. Section 3 contains the empirical tests. We conclude in Section 4. In the Appendix we present a simple model of political support for capital market funding, drawn from Perotti and von Thadden (2006).

\section{History and causes of pension funding}

The creation of modern pension systems occurred largely after the Second World War. The earliest pension system was created in Germany under Bismarck, who legislated a mandatory program for some categories of workers, especially in large firms 
where they were most exposed to socialist ideas (Lindert, 1994, and Cutler and Johnson, 2004). The program relied on worker and firm contributions and enjoyed some fiscal benefits. The pension claims were extremely modest, and could be drawn only upon reaching 70 years of age, at a time where most workers die well before 60 years. Interestingly, the contributions were invested in financial securities, just as the programs which imitated the German example in subsequent years in other European countries. Interestingly, the program had no redistributive feature (Lindert, 1994). For several decades, most states had no direct role in worker pensions, limiting state pensions to civil servants and war veterans.

In the five decades prior to WW1, the so-called "Victorian" period, the western world was largely at peace. Industrial productivity rose rapidly, albeit with wide swings, and prices were stable or declining. Long-term contracts for house and land rentals were common; long term fixed rate debentures normal. In the UK, government debt included a fair share of perpetual bonds with a fixed nominal rate. While there were sharp stock market crises, occasional bank failures and railway bankruptcies, their financial impact were circumscribed to few wealthy individuals, while price stability ensured financial stability for individuals who had deposits, bonds, rental income or other nominal assets.

The destruction of World War in 1914, after fifty years of peace, caught Europe by surprise. After the war, countries which had seen heavy fighting on their territory faced huge costs of reconstruction, while the loser countries faced massive reparations and suffered large losses of control over territory or industry. Social demands rose rapidly as veterans came back armed amid fears of a socialist uprising. These urgent spending needs often could not be fiscalized given the economic destruction.

In these countries, governments were forced into rapid money printing, leading to a sharp acceleration in inflation. ${ }^{4}$ Austria and Germany experienced devastating hyperinflations, but also winners such as Italy, Belgium and France had massive price jumps. In contrast, the UK, which escaped invasion and direct damage, managed to finance its war expenditures by running down its large stock of private foreign assets against newly issued public debt. Its non European allies, such as the US or Australia,

\footnotetext{
${ }^{4}$ In occupied countries, such as Belgium and France, inflation took off during the war because the occupying forces took control of the printing press to fund their war efforts.
} 
were far from the area of war destruction and could also redistribute over time the war cost. Within Continental Europe, the Netherlands, Scandinavia and Switzerland who had managed to stay neutral were also spared. Some democratic countries which were not drawn in WW1 suffered sharp inflationary shocks as a result of civil wars (in our sample, Finland, Greece, Spain and South Korea).

The devaluation of long-term nominal contracts, diffused after a long price stability, hit all social classes, and hit hard the middle and lower middle class. Pensioners and small rentiers were wiped out; even owners of modest holdings of land or housing suffered from the devaluation of rent income. Many were reduced to sell real property to survive. By most contemporaneous accounts, a large fraction of the middle class lost all its financial holdings, small firms were hard hit, and wealth became much more concentrated (Eulenburg, 1924).

Other classes, of course, also suffered greatly from the economic devastation, but this did not alter their policy preferences, e.g. for redistribution. ${ }^{5}$ The inflationary shocks had a seismic effect because it hit a class which became politically critical after 1918, when most European countries moved to universal suffrage. In countries where the middle class had been impoverished, a political majority shifted support to less marketfriendly policies (in extreme case, such as in Italy, Germany, Spain, also to less democratic institutions) and to a greater role for corporatist policies, bank dominance over capital markets, and state intervention (Perotti and Thadden, 2006). Corporatist policies, with higher labor protection, weaker competition, and nationalistic policies, found support among both inside labor and inside capital. Anecdotal evidence even suggests that ownership concentration increased in some countries, such as Italy (Aganin and Volpin, 2003) and Sweden (Hogfeldt, 2006). ${ }^{6}$

The stock market crash of 1929 presumably hit hard mostly the moneyed classes, ${ }^{7}$ but led to a major depression and massive unemployment, which forced increased social programs everywhere, such as the establishment of state funding for some pensions and

\footnotetext{
${ }^{5}$ Piketty et al (2006) show that many very rich renters in France were financially devastated by the post WW1 inflation, reducing wealth inequality at the very top of the distribution.

${ }^{6}$ Roe (2006) argues that ownership concentration increased because capitalists sought to resist increased labor activism. Unfortunately the scarce data on ownership makes it hard to assess whether larger control blocks emerge in left oriented systems, with the visible exception of Sweden.
} 
the expansion of pension benefits. Yet in countries that had escaped high inflation (the Anglo-Saxon allies, most of Scandinavia, Switzerland and the Netherlands), the middle class remained supportive of financial markets. ${ }^{8}$ Thus at the time when the structure of a general pension system was decided, in these countries the political preference was to rely on market funding. In contrast, in the affected countries where minority investor rights had been weakened, the pension system was entrusted to the state, even as this implied a sharp reversal relative to their early history of funded pension systems.

The largest inflationary shock came in almost all countries in our sample before WW2. ${ }^{9}$ Some countries, such as France, had already extended pension provisions in the late 1930s, but for most countries the establishment of the major social security program (defined as a comprehensive retirement program covering most production workers) came after WW2. Table 1 provides an overview of the estimated timing of major pension initiatives across countries, and suggest that the structural decisions on pension structure took place after the major financial crises of the interwar period.

\section{Alternative causes of pension structure}

We start by ruling out a mechanical interpretation of the inflationary shocks impact. When the price shocks occurred, pension benefits were very limited, and covered mostly workers employed in large firms, which funded pension payments themselves. Since inflation certainly caused losses to any dedicated reserves, one may speculate that shifting to a state-funded pension system may have been the only choice to secure these retirement claims. Yet pension claims were minimal at that time, as life expectancy was much lower than today and payments required work until the age of 70. Even if a state subsidy had been needed to cover an immediate shortfall, there was no reason to extend it to cover future claims, for which adequate funding could be built up by contributions. Neither in France nor in Germany there was a state bailout of the pension system after the

\footnotetext{
${ }^{7}$ While lenders and bondholders gained from large price declines, fewer individuals received these capital gains in countries where financial holdings had become less diffused.

${ }^{8}$ In fact, minority investor protection improved in these countries, setting the basis for further development. Examples are the establishment of the SEC and laws against concentration of financial power in the US in the 1930s, and a revised company law in the UK shortly after WW2.
} 
price jumps following the First World War. ${ }^{10}$ Thus it does not appear that the early price shocks forced the introduction of state pension funding. In contrast, pension funding by firms was much more threatened in the 1930s great depression, where failures were much more common than after WW1. The Great Depression shocked confidence on private firm pensions also in the US, which introduced Social Security in 1935.

A first explanation is that market funding will be chosen in countries with a high level of capital market development. Indeed there is correlation between pension funding and market capitalization (Table 2, Panel B), but the direction of causation is ambiguous: large pension funds provide long-term stable demand for securities. ${ }^{11}$ Accordingly, we control for independent explanations for capital market development. La Porta et al $(1997,1998)$ have shown that countries from the common law tradition have on average better investor protection than civil law countries. Common law countries may thus have developed funded systems while civil law countries chose unfunded systems based on a state guarantee. The evidence suggests that pension funding is not related to historical (pre-shock) measures of financial development or its legal determinants.

A simpler political economy explanation suggests that a political majority in a society with more income inequality prefers more fiscal redistribution, which may be best achieved via a state pension system funded by progressive taxation. ${ }^{12}$ We test this hypothesis by controlling for measures of income inequality around the time of the pension funding decision (see Deininger and Squire, 1996, and Forbes, 2000) in their present form. Interestingly, income inequality is negatively correlated with private funding, but our measures of political shocks remains very significant.

A separate redistributive issue arise if at the time of the decision the proportion of the population close to its retirement age was large. Conesa and Krueger, 1999, and

\footnotetext{
${ }^{9}$ Japan suffered hyperinflation just after WW2, and subsequently experienced a major reorientation of its financial system with increasing insider and bank dominance, coupled with better labor protection.

${ }^{10}$ Many Eastern European countries, where the role of the state had been discredited by their communist past, chose precisely to couple state guarantee for older cohorts with pre-funding for younger workers.

${ }^{11}$ Pension funds may also increase total savings if they induce forced savings or if they have a coordinating role, e.g. by avoiding panics among dispersed investors or provide better diversification.

${ }^{12}$ State funding does not imply more redistributive pensions in practice. The more redistributive pension systems appear to be those where their state funded component is smaller, and thus mainly targeted to lower income groups (such as the UK). In countries where state funding is more important are less redistributive, as pension claims are more closely linked to wages. More generally, there appears to be no empirical evidence of larger fiscal redistribution in more unequal countries.
} 
Cooley and Soares, 1999, argue that the age of the median voter is a critical driver of political support for a PAYG system, which tend to benefit the older generations beyond their past contributions. The result shows that a measure of the proportion of the older population around the time of the main pension choice is not significant.

We consider finally whether very negative experiences with large financial crises in the past have affected the population's attitude towards security markets, and created demand for state insurance for retirement income. The correlation of inflationary shocks with pension funding may derive from a psychological response from large financial losses on bond markets. We accordingly control for other large negative financial shocks that had no comparable redistributive effect for pivotal voters. The 1929 stock market crash turns out to have no significant effect on pension funding. In contrast, average stock returns, which have a direct impact on invested pension assets, do have a positive and significant effect.

Finally, we check whether there is an effect of inflation per se, using average inflation rather than its extreme values, and whether the political system is based on a majoritarian or proportional electoral voting rule. ${ }^{13}$ All these variables turn out not to be significant.

\section{Empirical analysis}

This section describes the sources of data and the construction of the variables and present the empirical analysis.

\section{Data Sources and Description of Variables}

Our measure of private pension funding is the ratio of capitalized private pension assets to GDP or to an estimate of pension liabilities. We use OECD data (OECD Newsletter, 2005) which includes all types of pension plans: occupational, personal, mandatory and voluntary. Asset reserves from social security systems, reflecting

\footnotetext{
${ }^{13}$ Whenever voters make policy choices based on more than one dimension, coalitions may be crucial. There is evidence that majoritarian systems, where coalition are less common, have smaller governments and welfare programs relative to proportional systems (Persson and Tabellini, 2004).
} 
government bonds held by the state itself, are excluded. This seems a reasonable measure of private funding, provided that private pension liabilities are not significantly underfunded, while public liabilities are unfunded. This is shown graphically in Figure 3.

We include all countries where current pension assets reflect a historical choice taken under a democratic government, so we exclude former Communist countries. The variable PENSION represents the percentage of funded pension assets over GDP in 2004, while PENSION+LIFE also includes accumulated life insurance assets. ${ }^{14}$

Information on price series was collected mainly from the Global Financial Database (from Global Financial Data Corporation). For some countries, we completed the time series from other sources (Maddison, 1991, Mitchell, 1992, as well as national banks and governmental statistical agencies). We constructed several variables for inflationary shocks, reported in Table 2 . The variable SHOCK is a dummy variable equal to one if the country experienced a period of extremely high inflation during 1900-1970, defined as an annual increase in consumer price index (CPI) of over $400 \%$. HIGH_INFLATION is a dummy variable equal to one if the country's highest annual increase in CPI in the period 1900 to 1970 was at least $30 \%$. (No results are affected if we increase the threshold to $50 \%$ or $70 \%$ ). As a final measure, we use the actual highest annual increase in CPI in the given period (denoted MAX_CPI). For countries that experienced hyperinflation, we set their value to the highest level for those countries that did not have experience hyperinflation (i.e., to $491.6 \%$, for Italy).

We take from La Porta et al. (1997) the legal origin dummy variable, defined as one for English legal origin (common law countries) and labeled COMMON_LAW. ${ }^{15}$ We further collect from OECD (2004) stock market capitalization in 2002 for all countries, denoted by MARKET_CAP. The percentage of catholics in each country and information whether electoral rule is majoritarian or not are taken from Tabellini et al $(2003) .^{16}$

\footnotetext{
${ }^{14}$ We performed the same analysis on pension assets data of 2002, with very similar results.

${ }^{15}$ Iceland is not included in the study of La Porta et al. (1997), but it has Scandinavian legal origin (Iceland is a former Norwegian crown colony, and was later ruled by Denmark until 1814).

${ }^{16}$ For both of these variables, we use current information, assuming that it did not materially change in the meantime.
} 
We collect data on alternative factors that may have affected preferences or beliefs during the period under consideration. To explore the impact of other crises, ${ }^{17}$ we construct a variable CRASH1929 which captures the size of the crash in the domestic stock market from the market high until the through (Taylor, 2002). We also collect data on demographics, specifically the proportion of older people, at different points in time. Its current value controls for the stock of pension liabilities, while its value at the time of the pension decision measures the size of a political block favorable to a fiscalization of pensions. The variable $\mathrm{POP}_{-} 65+$ measures the proportion of the population over 65 years old, using US Census information (cf. www.census.gov/ipc/www/idbsprd.html). The historical values are taken for 1950, in some cases for either 1951 or 1960-1961 if data is not available for earlier years. Finally, to test the impact of income inequality, we use the historical data around the historical pension choice from Forbes (2000).

We have complete information on 16 countries and partial information on 8 more countries. For all 24 countries, we do have information on inflation and pension assets.

\section{Descriptive Statistics}

Table 2 shows the summary statistics. On average, the ratios of funded pension and life insurance assets over GDP of 61.6\% in 2004 (34.3\% for pension assets only). There is great dispersion in the sample, with a minimum of $0 \%$ for Greece and a maximum of $153 \%$ for Switzerland. The median is $54.1 \%$, somewhat lower than the mean. The US had a fraction of funded pension and life insurance assets over GDP of $115 \%$, higher than the sample average but by no means the highest.

Overall, $25 \%$ of the countries in our sample experienced a dramatic inflationary shock or hyperinflation during the period considered (the dummy variable SHOCK). Moreover, Table 2 indicates that $62.5 \%$ (i.e., 15 countries) had a period of sharply high inflation (at least 30\% increase in CPI in a single year). A quarter of the sample is composed of common law countries.

\footnotetext{
${ }^{17}$ Note that some countries experienced their stock market shock already in 1928 (for some countries, the market top is already earlier). See Taylor (2002) for more details on each country's exact date.
} 
The stock market crashes of 1929-1930s caused huge share price drops around the world, about $65 \%$ on average. The dispersion however is relatively low (the standard deviation is $14.3 \%$ ). The largest decrease in stock prices was experienced in the US, with $86.2 \%$, but other countries had a stock crash quite similar in magnitude.

There is very little variation among countries in the proportion of older people in the population (POP1950_65+), with an average of 8.7\%. While this suggests that the hypothesis can only have a modest explanation power, it may make difference at the margin, if senior citizens are politically pivotal.

Figure 1 presents the univariate relationship between PENSION_LIFE and the dummy variable SHOCK graphically. It clearly indicates a negative link between inflationary shocks and accumulated pension assets, and suggests that outliers do not drive these results. This is confirmed by similar graphs using the other inflation variables (not shown here). Figure 2 shows the relationship between legal origin and funded pension assets. There, the link appears less clear, although the figure seems to indicate a slightly positive relationship.

\section{$\underline{\text { Empirical tests }}$}

Table 3 gives our basic results. The effect of an inflationary shock on funded assets is very strong, whatever the specifications of the shock. Countries that experienced a sharp inflationary shock subsequently favored an unfunded pension system. The effect is economically significant, since (in the univariate setting; cf. Regression 1 in Panel A) such countries have 58.5\% less funded pension and life insurance assets in 2004 than countries that did not have hyperinflation. Moreover, this variable already explains $31 \%$ of the variation alone. The variable SHOCK remains significant when estimated together with HIGH_INFLATION (Regression 2), indicating that extreme inflation has much explanatory power, but that pension asset are also quite affected by a high inflation experience. Reassuringly, our results hold if we use a continuous variable MAX_CPI (Regression 3). ${ }^{18}$

\footnotetext{
${ }^{18}$ It is not possible to estimate SHOCK and MAX_CPI jointly, given to very their high correlation (95\%).
} 
Regression 4 (Table 3, Panel A) shows that common law countries do not have a greater propensity to a more privately funded pension system. Legal origin explains little of the variation compared to our measure of wealth distribution shocks. In Regressions 5 -6 , when we examine both hypotheses jointly, its sign is negative, while the inflationary shock remains significant and at the same level of magnitude as in the univariate analysis. Also the improvement of $\mathrm{R}^{2}$ is marginal.

In our sample, we do not have any legal origin countries which experienced a major inflationary acceleration (i.e. SHOCK takes the value one). Ideally, we would have wanted to include an interactive term SHOCK*COMMON_LAW. Instead, we consider the effect of legal origin in the sub-sample of countries that did not experience an inflationary shock (Regressions $7-9$, Table 3). Surprisingly, even in this selected sample legal origin does not contribute in explaining pension funding. ${ }^{19}$

We next test whether non-democracies exhibit a different pattern. A dummy variable takes value one if the countries were not democratic at the time the major pension plan was put in place, which is the case of Mexico, Portugal, South Korea and Spain. The non-democracy dummy is highly significant and negative (Regression 10). The inflationary shock variables remain highly significant and of the same magnitude, even in the sub sample of countries that were democracies (Regressions 11-12).

In Table 4, we estimate the basic relationship using alternative measures of private pension funding. In Regressions $1-4$, we exclude life insurance reserves from the accumulated pension assets (the variable PENSION), obtaining similar results. Next we control for the level of unfunded pension liabilities. Although no OECD data is available for our sample, we estimate liabilities by capitalizing annual old age benefit expenditures in each country. ${ }^{20}$ Data on annual old age benefits expenditures by governments were obtained from OECD Social Expenditures Database (SOCX). In Regression 5-8 (Table 4), we run regressions on similar specifications but using funded pension assets (PENSION_LIFE) as percentage of total pension liabilities (PENSION_LIFE plus estimated unfunded pension liabilities). The effect of inflationary shocks remains strongly significant.

\footnotetext{
${ }^{19}$ This leaves the question why common law countries did not experience high inflation. We will show later that none of them has been subject to military invasion or major war devastation.

${ }^{20} \mathrm{We}$ capitalize liabilities by discounting at $5 \%$ a perpetual annuity based on current pension payments.
} 
$\underline{\text { Robustness and Alternative Specifications }}$

Table 5 investigates some alternative hypotheses and controls: the importance of older people in the population (POP1950_65+) in 1950, the impact of the stock markets crash of 1929-early 1930s (CRASH1929), stock market returns (STOCK_RETURNS), stock market capitalization (current MARKET_CAP and market capitalization in 1913), average annual inflation over several time periods (1901-1945 and 1920-1945), ${ }^{21}$ and the percentage of Catholics in total population.

As mentioned earlier, the stock market crash of 1929 may have had a similar effect on the willingness of individuals to rely on capital markets. In this case, we expect also a negative impact of CRASH1929 on the size of accumulated pension assets.

On the other hand, if the proportion of older people in the population was large at the time of the pension choice, we may expect greater support for an unfunded pension system that enables immediate and more generous payments of pensions.

We expect a positive, even mechanical effect on pension funding from stock market returns. We also test for the effect of current stock market capitalization, although this variable is highly endogenous. Accordingly, we also use market capitalization value in 1913 , i.e. prior to any inflationary shock.

The next control variable concerns average inflation over two different time periods. Our conjecture states that inflationary shocks create wealth redistribution and shifts in support away from investor protection, but inflation per se should not matter. Finally, we control for the percentage of total population that is catholic. In previous studies, this factor has been shown to affect financial development (Stulz and Williamson, 2003) and social security developments (Cutler and Johnson, 2004). Here however, it has little explanatory power and does not affect the significance of inflationary shocks.

\footnotetext{
${ }^{21}$ For the calculation of average annual inflation in each country, we excluded years of particularly high inflation, in particular of hyper-inflation and possible run-ups. For some countries, we did not have a sufficiently long time period to include them. In this case, we only included them if not more than three years of data was missing.
} 
We find no support for a direct role of demography (Regressions 1 - 3, Panel A) nor the crash of 1929 (Regression 4 - 6, Panel A), even in a univariate setting. Among the controls, long-run stock market returns are significant (Regressions 7 - 9, Panel A), although they do not affect the significance of the political shocks. Current stock market capitalization is significant, as expected, but its value in 1913 never is (Panel B). We expect current capitalization to be co-determined with pension funding by a historical political preference. The political channel remains significant even to the inclusion of current stock market capitalization.

In Regressions 5 - 8 of Panel B, we control for average yearly inflation. Results indicate that only shock to inflation matter, not inflation per se.

In Table 6, we test the alternative political economy hypothesis that income inequality (as opposed to wealth inequality) was critical to pension funding, under the presumption that state pensions are more redistributive, or offer more social insurance. We use income inequality data from Forbes (2000) on the Gini coefficient in income distribution in the 1960s. Interestingly, more unequal society do rely more on state funding, but this effect is less significant than the wealth inequality shocks caused by the price shocks. Possibly, this other political factor contributed particularly to shape the redistributive or social insurance features of the pension system. In Table 6, we further investigate whether the electoral voting rule matters for the choice of pension system (Regressions $4-6$ ). While it helps explaining this choice when looking at a univariate setting, it becomes insignificant when including inflationary shock as additional explanatory variable.

\section{Exogeneity of shocks}

A critical question is whether the variation in inflationary shocks is indeed exogenous. While the main cause of such shocks were devastating world and civil wars which can be reasonably treated as exogenous, high inflation is ultimately the result of a money supply choice, often with an ultimate fiscal cause (Sargent and Wallace, 1981). Of course, money printing may be the sole resort in the aftermath of a major war. Countries which experienced heavy destruction face urgent demands for large public expenditures, 
just when the ability to rapidly raise fiscal revenues is at its lowest point. If spending needs are massive and no alternative funding exists, there is little choice but to print money. ${ }^{22}$ Moreover, inflation often started during the war in invaded countries, as the occupiers captured money printing for their own needs (e.g. in France and Belgium). Yet it is possible that, for a given amount of war destruction, some governments chose to print money, while others to resist spending. It may be argued that inefficient redistribution via inflation is more likely when the excutive is subject to weak constraints. Accordingly, we verify whether the response of prices to war damage is correlated with the quality of political institutions at the time.

We measure war destruction in two ways. The most direct is a continuous variable, the change in population from 1914-1919 (data are drawn from Maddison, 1991). The other one is a self-constructed index of war destruction. It is built on three different dummy variables: whether the country was invaded during the world war associated with its major inflationary shock (or WW1 if no such shock ever occurred), whether fighting on the territory was intense, and whether the war resulted in major losses in territory; see the note in Table 7 for a more detailed description. This index ranges from 0 to 3 , with a larger value implying greater war devastation.

Using historical measures for political institutions from the Polity IV database, we use measures of the composite index POLITY and the measure of quality of democracy DEMOC. ${ }^{23}$

Table 7 seeks to explain price shocks in terms of war shocks, the contemporaneous measure of political institutions, and an interaction term. Under our conjecture, only the war shock should be significant, which is clearly the case across all measures of war damage. This suggests that inflationary shocks were indeed driven by exogenous shocks, rather than being an avoidable choice undertaken by countries with poor constraints on the executive.

\footnotetext{
${ }^{22}$ Urgency after both wars will have been encouraged by veterans with recent military training coming to demonstrate in the capital, and the spread of socialist ideas.

${ }^{23} \mathrm{We}$ also ran the same regressions with the degree of independence of executive authority XCONST from the same database. The results were qualitatively very similar. This variable is also highly correlated with Polity.
} 


\section{Conclusions}

This paper provides evidence that current pension funding reflects historical choices between market pre-funding and state guarantee were driven mainly by political preferences. Such choices presumably persisted because they had a direct reinforcing effect, and because they were consistent with contemporaneous choices on the governance of the financial system. In the first place, the pension funding choices were paralleled, and in some cases anticipated, by political choices about the role of markets versus institutions and large investors in corporate governance, which reinforced the pension structure chosen. Second, an indirect effect was caused by the impact of the initial choices on the diffusion of shareholdings and thus on political support for investor rights.

Following Perotti and von Thadden (2006), we seek for evidence of a causal role for politics in pension funding choices in the history of the Great Reversals after the Second World War, and draw some consequences for pension reform. We then conclude that the two are both codetermined by political choices. A political economy approach can explain clusters of societal choices on financial system structure, corporate governance, and the extent of labor rents (Pagano and Volpin, 2005; Perotti and von Thadden, 2006). Among democracies, there is evidence of positive correlation of labor rents with bank, state or family governance and high private control benefits, and negative with investor protection.

These initial choices had a major self-reinforcing effect for two main reasons. In the first place, the pension funding choices were paralleled, and in some cases anticipated, by political choices about the role of markets versus institutions and large investors in corporate governance, which reinforced the pension structure chosen. Second, an indirect effect was caused by the impact of the initial choices on the diffusion of shareholdings and thus on the political preferences of a majority.

Our instrument to establish causality is variation in inflationary shocks. Even before the clear statement in Sargent and Wallace (1981), it has been recognized that high inflation is a fiscal phenomenon. All the episodes of high inflation in our sample have followed devastating world or civil wars, natural causes for sudden, urgent fiscal need. In 
contrast, in the sample of countries that never experienced a major war-related price shock, the highest recorded inflation is associated with the oil shock of the 1970s.

In the aftermath of a destructive conflict, demands for public expenditures are extremely high, just at a time when the ability to raise fiscal revenues is at its lowest point. This pressure can be dramatic, given the need to demobilize troops and rebuild the infrastructure. Clearly, if it is impossible to find alternative funding methods, the military shock forces high inflation.

Our identification benefits from some variation in our small sample of democracies. There are examples of countries that experienced intense warfare and did not suffer high inflation. With no exceptions, these are countries that did not experience military invasions, such as the UK in both world wars. Such countries managed to fiscalize high war costs, so they were able to distribute over time the public spending shock. Yet there are countries that did not suffer any military destruction, such as Germany in WW1, where hyperinflation was the consequence of a high reparation burden. The political consequences of such shocks cannot be underestimated, as Keynes stated eloquently in his Political Consequences of the World War (1920).

In conclusion, we argue that pensions are a highly political issue, and any reform will be driven by the political economy of this decision. The determinants of the historical choices on pension structure, of course, may be reversed. Many Continental European capital markets recovered in the last two decades also thanks to a massive privatization program, which produced more financial participation and thus more political support for capital markets (Biais and Perotti, 2002).

In the end, understanding the political determinants of pension structure is essential to help identifying the range of feasible solutions, and to predict to what extent structural features of existing systems, such as solidarity and coinsurance features, will persist. An important research theme in the future should be to identify the determinants also of claim coinsurance and redistribution across pension systems. 


\section{REFERENCES}

Aganin, Alexander and Paolo Volpin (2003), The History of Corporate Ownership in Italy, forthcoming in Randall Morck (ed.), The History of Corporate Ownership, University of Chicago Press.

Biais, Bruno and Enrico Perotti (2002), Machiavellian Privatization, American Economic Review 92, 240-258.

Caucutt, Elizabeth, Thomas F. Cooley and Nezih Guner (2006), The Farm, the City, and the Emergence of Social Security, unpublished manuscript.

Conesa, Juan C. and Dirk Krueger (1999), Social Security Reform with Heterogeneous Agents, Review of Economic Dynamics 2, 757-795.

Cooley, Thomas F. and Jorge Soares (1999), A Positive Theory of Social Security Based on Reputation, Journal of Political Economy 107 (1), 135-160.

Cutler, David M., and Richard Johnson (2004), The Birth and Growth of the Social Insurance State: Explaining Old Age and Medical Insurance across Countries, Public Choice 120, pp. 87-121.

Deininger, Klaus and Lyn Squire (1996), A New Data Set Measuring Income Inequality, World Bank Economic Review 10 (3), pp. 565-591.

Flora, Peter (ed.) (1987), Growth to Limits: The Western European Welfare States Since World War II .Volume I and II, Walter De Gruyter

Forbes, K.J. (2000), A Reassessment of the Relationship between Inequality and Growth, Amercian Economic Review 90 (4), 869-887.

Högfeldt, Peter (2004), The History and Politics of Corporate Ownership in Sweden, unpublished manuscript, Stockholm School of Economics.

La Porta, R., F. Lopez-de-Silanes, A. Shleifer, and R. Vishny (1997), Legal Determinants of External Finance, Journal of Finance 52 (3), 1131-1150.

La Porta, R., F. Lopez-de-Silanes, A. Shleifer, and R. Vishny (1998), Law and Finance, Journal of Political Economy 106, 1113-55.

Lindert, Peter H. (1994), The Rise of Social Spending, 1880-1930, Explorations in Economic History 31, pp. 1-37.

Maddison, A. (1991), Dynamic Forces in Capitalist Development: A Long-Run Comparative View, Oxford University Press. 
Meyer, J. (2004), Inertia Creeps: Reforming the German Public Pension System, Journal of Australian Political Economy 53, 207-219.

Mitchell, B.R. (1992), International Historical Statistics: Europe 1750-1988, Stockton Press.

OECD Newsletter (2005), Pension Markets in Focus, Newsletter December, Issue 2.

Pagano, Marco and Paolo Volpin (2005), The Political Economy of Corporate Governance, American Economic Review 95: 1005-30.

Perotti, E., and E. von Thadden (2006), The Political Economy of Corporate Control and Labor Rents, Journal of Political Economy.

Piketty, Thomas, Postel-Vinay G., Jean Laurent Rosenthal (2006), Wealth Concentration in a Developing Economy: Paris and France, 1807-1994, American Economic Review, vol. 96, no 1, 2006, p. 236-256

Roe, Mark (2006), Legal Origins and Stock Markets in the Twentieth Century, unpublished manuscript, Harvard Law School.

Stulz, R., R. Williamson (2003), Culture, Openness, and Finance, Journal of Financial Economics 70 (3), p. 313-349.

Tabellini, G., T. Persson and F. Trebbi (2003), Electoral Rules and Corruption, Journal of the European Economic Association.

Tabellini, G., T. Persson, Constitutional Rules and Fiscal Policy Outcomes, American Economic Review, March 2004

Taylor, B. (2002), Could this Decade be the Next 1930s? A Review of World Stock Markets in the 1920s, < http://www.globalfinancialdata.com/articles/1929.pdf $>$. 


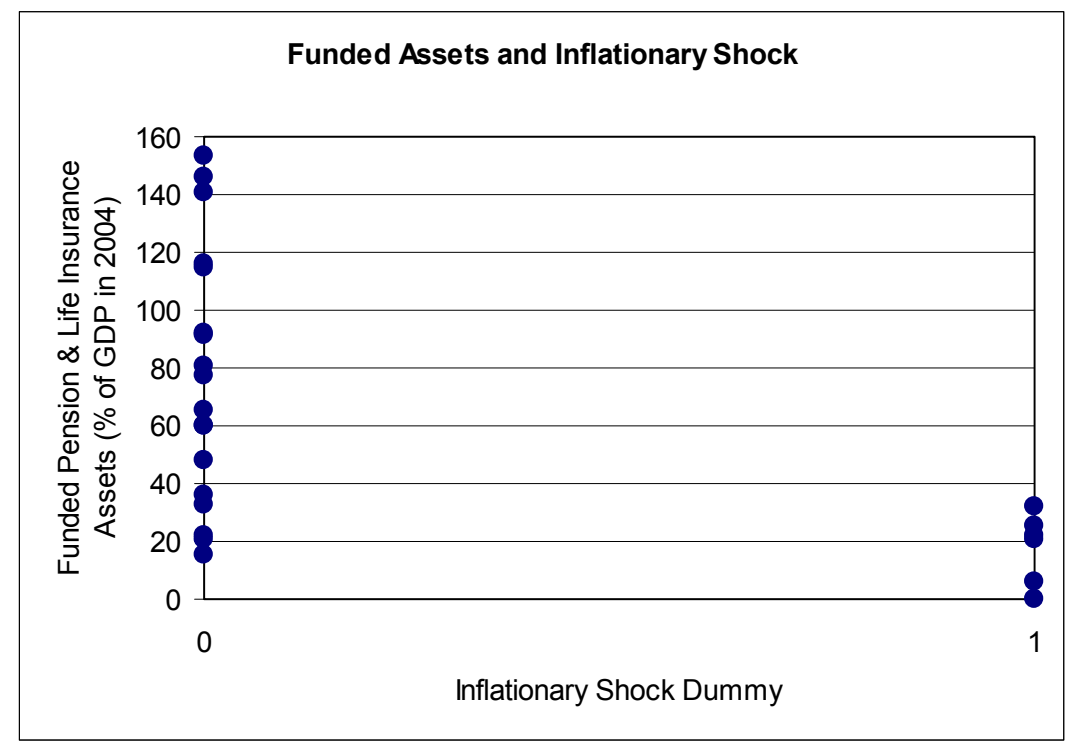

Note: Figure 1 shows total funded pension and life insurance assets as percentage of GDP in 2004 (the variable PENSION+LIFE) on the x-axis and SHOCK dummy (as defined in Section 3 ) on the y-axis.

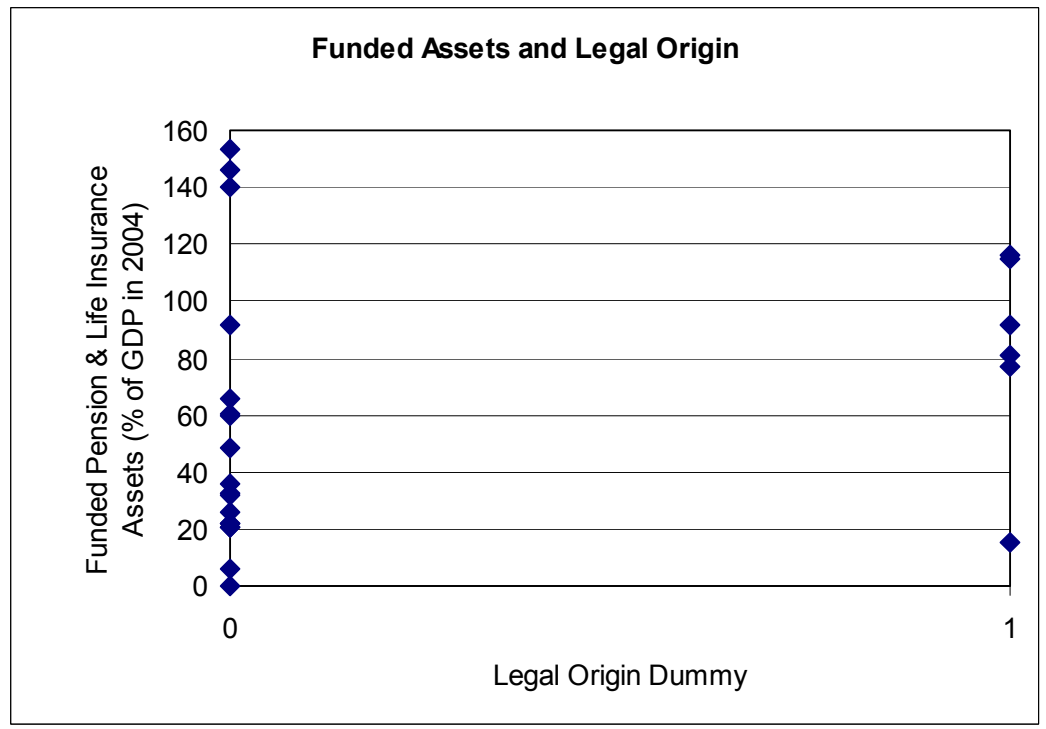

Note: Figure 2 shows total funded pension and life insurance assets as percentage of GDP in 2004 (the variable PENSION+LIFE) on the $x$-axis and Common Law dummy on the $\mathrm{y}$-axis. 


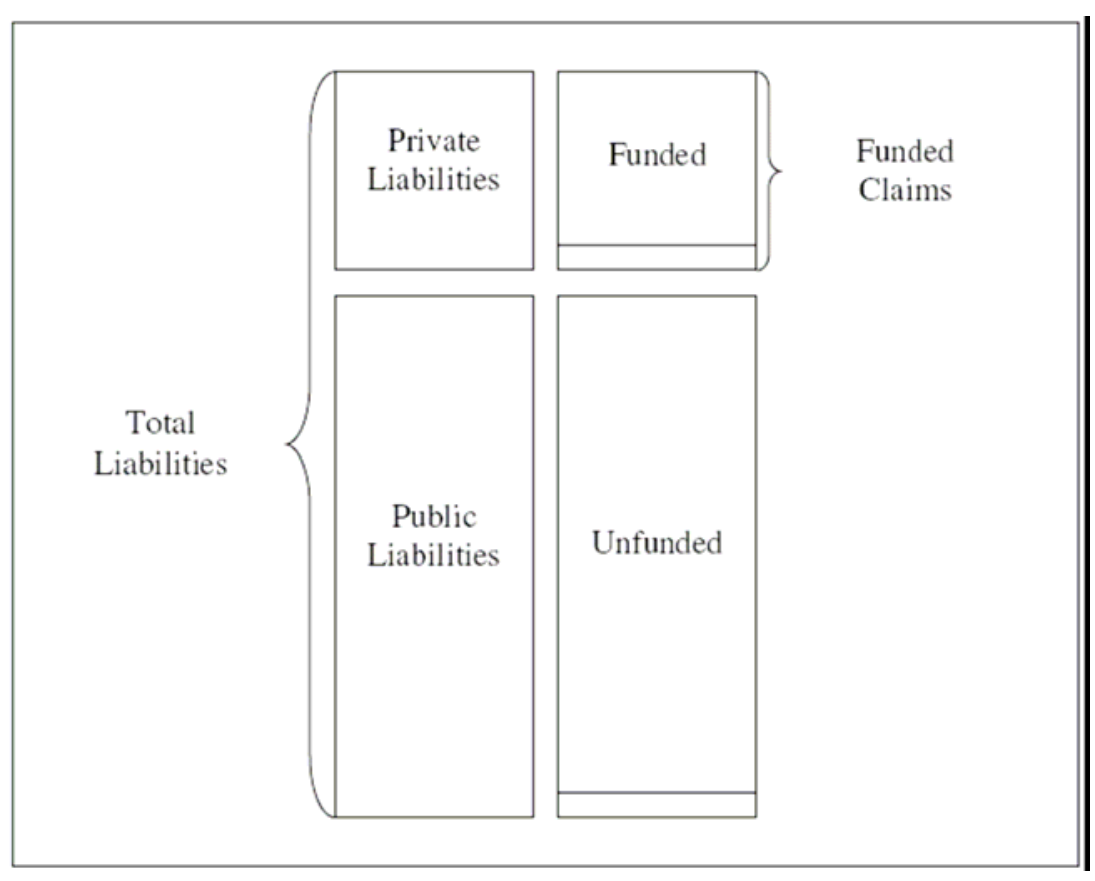

Note: Figure 3 shows the calculation of funded pension assets (or "funded claims") as percentage of total pension liabilities. 
Table 1: Development of Pension Systems in Various Countries

\begin{tabular}{|c|c|c|}
\hline Country & Year of First Program & Year of First Major Program \\
\hline Australia & 1908 & 1941 \\
\hline Austria & 1909 & 1935 \\
\hline Belgium & 1900 & 1967 \\
\hline Canada & 1927 & 1966 \\
\hline Denmark & 1891 & 1964 \\
\hline Finland & 1937 & 1956 \\
\hline France & 1910 & 1945 \\
\hline Germany & 1889 & 1949 \\
\hline Greece & 1934 & $1978-85$ \\
\hline Iceland & 1909 & $1969-70$ \\
\hline Ireland & 1908 & 1952 \\
\hline Italy & 1919 & 1969 \\
\hline Japan & 1875 & $1942-44$ \\
\hline South Korea & 1960 & 1973 \\
\hline Mexico & $1943-44$ & $1943-44$ \\
\hline Netherlands & 1913 & 1957 \\
\hline New Zealand & 1898 & 1938 \\
\hline Norway & 1936 & 1936 \\
\hline Portugal & 1919 & 1935 \\
\hline Spain & 1919 & 1939 \\
\hline Sweden & 1913 & 1962 \\
\hline Switzerland & 1946 & 1946 \\
\hline United Kingdom & 1908 & 1948 \\
\hline United States & 1896 & 1935 \\
\hline
\end{tabular}

NOTE: "Year of First Program" typically involves only a particular group of society (e.g., veterans, war widows, miners). "Year of First Major Program" is based on programs involving "large coverage" of private sector. Main sources of information for the Year of First Program and Major Program are: Flora (1987a, 1987b) (for various European countries), the U.S. Social Security Administration (on: Social Security Programs Throughout the World), the Australian Bureau of Statistics, the Financial Report on the Public Pension Plan System (Japan) and the French Observatory of Retirement. 
Table 2: Summary Statistics and Correlation Matrix

\begin{tabular}{|c|c|c|c|c|c|c|}
\hline \multicolumn{7}{|c|}{ Panel A: Summary Statistics } \\
\hline Variables & Mean & Median & Minimum & Maximum & $\begin{array}{l}\text { Standard } \\
\text { Deviation }\end{array}$ & Nbr. Obs. \\
\hline PENSION+LIFE & 61.63 & 54.10 & 0.00 & 153.20 & 46.32 & 24 \\
\hline PENSION & 34.31 & 12.00 & 0.00 & 111.90 & 38.92 & 24 \\
\hline SHOCK Dummy & 0.250 & 0.000 & 0.000 & 1.000 & 0.442 & 24 \\
\hline HIGH_INFLATION Dummy & 0.625 & 1.000 & 0.000 & 1.000 & 0.495 & 24 \\
\hline MAX_CPI & 173.9 & 52.6 & 13.1 & 491.6 & 201.7 & 22 \\
\hline COMMON_LAW Dummy & 0.250 & 0.000 & 0.000 & 1.000 & 0.442 & 24 \\
\hline CRASH1929 & 64.8 & 65.0 & 39.4 & 86.2 & 14.3 & 16 \\
\hline MARKET_CAP & 0.723 & 0.436 & 0.146 & 2.044 & 0.572 & 22 \\
\hline NON-DEMOCRACY Dummy & 0.167 & 0.000 & 0.000 & 1.000 & 0.381 & 24 \\
\hline POP1950_65+ & 0.087 & 0.089 & 0.035 & 0.122 & 0.023 & 24 \\
\hline POP2004_65+ & 0.147 & 0.155 & 0.055 & 0.191 & 0.034 & 24 \\
\hline STOCK_RETURNS & 3.129 & 3.020 & -0.120 & 5.880 & 1.773 & 23 \\
\hline \multicolumn{7}{|c|}{ Panel B: Correlation Matrix } \\
\hline & $(1)$ & $(2)$ & (3) & $(4)$ & $(5)$ & $(6)$ \\
\hline (1) PENSION+LIFE & 1 & & & & & \\
\hline (2) PENSION & $0.938 * * *$ & 1 & & & & \\
\hline (3) SHOCK Dummy & $-0.559 * * *$ & $-0.472 * *$ & 1 & & & \\
\hline (4) HIGH_INFLATION Dummy & $-0.621 * * *$ & $-0.628 * * *$ & $0.447 * *$ & 1 & & \\
\hline (5) COMMON_LAW Dummy & 0.268 & 0.336 & -0.333 & $-0.745^{* * *}$ & 1 & \\
\hline (6) MARKET_CAP & 0.648 *** & $0.657^{* * *}$ & $-0.445^{* *}$ & $-0.395 *$ & 0.186 & 1 \\
\hline
\end{tabular}


Table 3: The Political Choice of Pension System

\begin{tabular}{|c|c|c|c|c|c|c|}
\hline \multicolumn{7}{|c|}{ Panel A } \\
\hline Variables & (1) & $(2)$ & (3) & $(4)$ & (5) & (6) \\
\hline SHOCK & $\begin{array}{c}-58.52 \text { *** } \\
(11.58)\end{array}$ & $\begin{array}{c}-36.83^{* * *} \\
(13.70)\end{array}$ & & & $\begin{array}{l}-36.83 \text { ** } \\
(14.04)\end{array}$ & $\begin{array}{c}-38.81 \text { ** } \\
(17.56)\end{array}$ \\
\hline HIGH_INFLATION & & $\begin{array}{c}-43.38 \text { ** } \\
(18.68)\end{array}$ & & & $\begin{array}{c}-73.87^{* \star *} \\
(21.29)\end{array}$ & $\begin{array}{c}-72.30 \text { *** } \\
(23.37)\end{array}$ \\
\hline MAX_CPI & & & $\begin{array}{l}-0.15^{* * *} \\
(0.028)\end{array}$ & & & \\
\hline COMMON_LAW & & & & $\begin{array}{c}28.10 \\
(18.36)\end{array}$ & $\begin{array}{l}-45.73 \text { * } \\
(22.52)\end{array}$ & $\begin{array}{l}-47.64 \text { * } \\
(23.50)\end{array}$ \\
\hline POP2004_65+ & & & & & & $\begin{array}{l}-100.31 \\
(243.41)\end{array}$ \\
\hline Nbr. of Obs. & 24 & 24 & 22 & 24 & 24 & 24 \\
\hline R-squared & $31 \%$ & $48 \%$ & $45 \%$ & $7 \%$ & $57 \%$ & $57 \%$ \\
\hline \multirow[t]{2}{*}{ Adj. R-squared } & $28 \%$ & $43 \%$ & $42 \%$ & $3 \%$ & $50 \%$ & $48 \%$ \\
\hline & & & & & & \\
\hline \multirow[t]{2}{*}{ Variables } & $(7)$ & (8) & (9) & $(10)$ & (11) & $(12)$ \\
\hline & $\begin{array}{r}\text { Countries } \\
\text { (SH }\end{array}$ & $\begin{array}{l}\text { thout the La } \\
\mathrm{KK}=0 \mathrm{Subs}\end{array}$ & $\begin{array}{l}\text { st Shocks } \\
\text { iple) }\end{array}$ & & \multicolumn{2}{|c|}{$\begin{array}{c}\text { Excluding Non- } \\
\text { Democracies (NON- } \\
\text { DEMOCRACY = } 0 \\
\text { Subsample) }\end{array}$} \\
\hline SHOCK & & & & $\begin{array}{c}-49.08 \text { *** } \\
(14.41)\end{array}$ & $\begin{array}{c}-63.21^{* * *} \\
(12.44)\end{array}$ & $\begin{array}{c}-63.46 \text { *** } \\
(16.54)\end{array}$ \\
\hline HIGH_INFLATION & $\begin{array}{c}-43.38 \text { ** } \\
(18.53)\end{array}$ & & $\begin{array}{c}-73.87^{* * *} \\
(21.29)\end{array}$ & & & \\
\hline COMMON_LAW & & $\begin{array}{c}9.67 \\
(20.38)\end{array}$ & $\begin{array}{l}-45.73 \text { * } \\
(22.52)\end{array}$ & $\begin{array}{c}3.45 \\
(20.82)\end{array}$ & & $\begin{array}{c}-0.66 \\
(21.28)\end{array}$ \\
\hline Non-Democracy & & & & $\begin{array}{l}-37.31 \text { ** } \\
(14.91)\end{array}$ & NA & NA \\
\hline Nbr. of Obs. & 18 & 18 & 18 & 24 & 20 & 20 \\
\hline R-squared & $26 \%$ & $1 \%$ & $38 \%$ & $40 \%$ & $32 \%$ & $32 \%$ \\
\hline Adj. R-squared & $21 \%$ & $x$ & $30 \%$ & $32 \%$ & $28 \%$ & $24 \%$ \\
\hline \multicolumn{7}{|c|}{$\begin{array}{l}\text { NOTE: The dependent variable is the percentage of funded pension and life insurance assets over GDP in } 2004 \\
\text { (PENSION+LIFE). All the regressions include a constant, whose coefficient is not reported. The dummy variable SHOCK } \\
\text { is equal to one if the country experienced an increase in its Consumer Price Index (CPI) of } 400 \% \text { or more in a single year, } \\
\text { and zero otherwise. The dummy variable HIGH_INFLATION is equal to one if the country experienced an increase in CPI } \\
\text { of } 30 \% \text { or more in a single year, and zero otherwise. MAX_CPI gives the highest annual percentage increase in CPI in } \\
\text { the years prior to each country's first major pension program. COMMON_LAW is a dummy variable equal to one if the } \\
\text { country is a common law country, and zero otherwise. The variable POP2004_65+ measures for the proportion of the } \\
\text { total population over } 65 \text { years old in } 2004 \text {. The dummy variable NON-DEMOCRACY (i.e., countries that were not } \\
\text { democratic at time of first major political decisions on pension system were made) equals one for South Korea, Mexico, } \\
\text { Portugal and Spain. Regressions (11) and }(12) \text { are for the subsample NON-DEMOCRACY }=0 \text {. Robust standard errors } \\
\text { are in parentheses. Significance levels: }{ }^{* * *} \text { for } 1 \%,{ }^{* *} \text { for } 5 \%, \text { and }{ }^{*} \text { for } 10 \% \text {. }\end{array}$} \\
\hline
\end{tabular}


Table 4: Alternative Definitions of Pension Funding

\begin{tabular}{|c|c|c|c|c|c|c|c|c|}
\hline Variables & (1) & (2) & (3) & (4) & (5) & (6) & (7) & (8) \\
\hline & \multicolumn{4}{|c|}{$\begin{array}{c}\text { Funded Pension Assets, excluding Life Insurance } \\
\text { Reserves }\end{array}$} & \multicolumn{4}{|c|}{$\begin{array}{l}\text { Percentage of Funded Pension Assets } \\
\text { (PENSION+LIFE) from Total Liabilities }\end{array}$} \\
\hline SHOCK & $\begin{array}{c}-41.55^{* * *} \\
(9.58)\end{array}$ & $\begin{array}{c}-35.67^{* * *} \\
(13.16)\end{array}$ & $\begin{array}{l}-21.07^{*} \\
(12.14)\end{array}$ & $\begin{array}{c}-40.24^{* * *} \\
(14.88)\end{array}$ & $\begin{array}{c}-0.23^{* * *} \\
(0.06)\end{array}$ & $\begin{array}{c}-0.17^{* * *} \\
(0.06)\end{array}$ & $\begin{array}{l}-0.12 * \\
(0.07)\end{array}$ & $\begin{array}{l}-0.15^{* *} \\
(0.06)\end{array}$ \\
\hline HIGH_INFLATION & & & $\begin{array}{l}-58.38 \text { ** } \\
(26.49)\end{array}$ & & & & $\begin{array}{l}-0.19 * * \\
(0.07)\end{array}$ & $\begin{array}{l}-0.16^{* *} \\
(0.07)\end{array}$ \\
\hline COMMON_LAW & & $\begin{array}{c}17.65 \\
(17.37)\end{array}$ & $\begin{array}{l}-26.13 \\
(26.29)\end{array}$ & $\begin{array}{c}8.72 \\
(19.62)\end{array}$ & & $\begin{array}{l}0.16 \text { ** } \\
(0.08)\end{array}$ & $\begin{array}{c}0.02 \\
(0.09)\end{array}$ & $\begin{array}{c}0.00 \\
(0.08)\end{array}$ \\
\hline POP2004_65+ & & & & $\begin{array}{l}-290.30 \\
(193.62)\end{array}$ & & & & $\begin{array}{l}-1.44 \\
(1.20)\end{array}$ \\
\hline Nbr. of Obs. & 24 & 24 & 24 & 24 & 24 & 24 & 24 & 24 \\
\hline R-squared & $22 \%$ & $27 \%$ & $48 \%$ & $31 \%$ & $29 \%$ & $43 \%$ & $53 \%$ & $59 \%$ \\
\hline Adj. R-squared & $19 \%$ & $19 \%$ & $40 \%$ & $21 \%$ & $26 \%$ & $38 \%$ & $46 \%$ & $50 \%$ \\
\hline
\end{tabular}

NOTE: In Regressions (1)-(4), the dependent variable is the percentage of funded pension assets over GDP in 2004, excluding Life Insurance assets (PENSION). In Regressions (5)-(8), the dependent variable is the percentage of funded pension liabilities/assets (PENSION+LIFE) from total liabilities, i.e., funded liabilities and unfunded public pension liabilities (defined as 20 times old age social expenditures) in 2004. All the regressions include a constant, whose coefficient is not reported. The dummy variable SHOCK is equal to one if the country experienced an increase in its Consumer Price Index (CPI) of $400 \%$ or more in a single year, and zero otherwise. The dummy variable HIGH_INFLATION is equal to one if the country experienced an increase in CPI of $30 \%$ or more in a single year, and zero otherwise. MAX_CPI gives the highest annual percentage increase in CPI in the years prior to each country's first major pension program. COMMON_LAW is a dummy variable equal to one if the country is a common law country, and zero otherwise. The variable POP2004_65+ measures for the proportion of the total population over 65 years old in 2004. Robust standard errors are in parentheses. Significance levels: ${ }^{* * *}$ for $1 \%$, ${ }^{* *}$ for $5 \%$, and ${ }^{*}$ for $10 \%$. 
Table 5: Possible Alternative Explanations

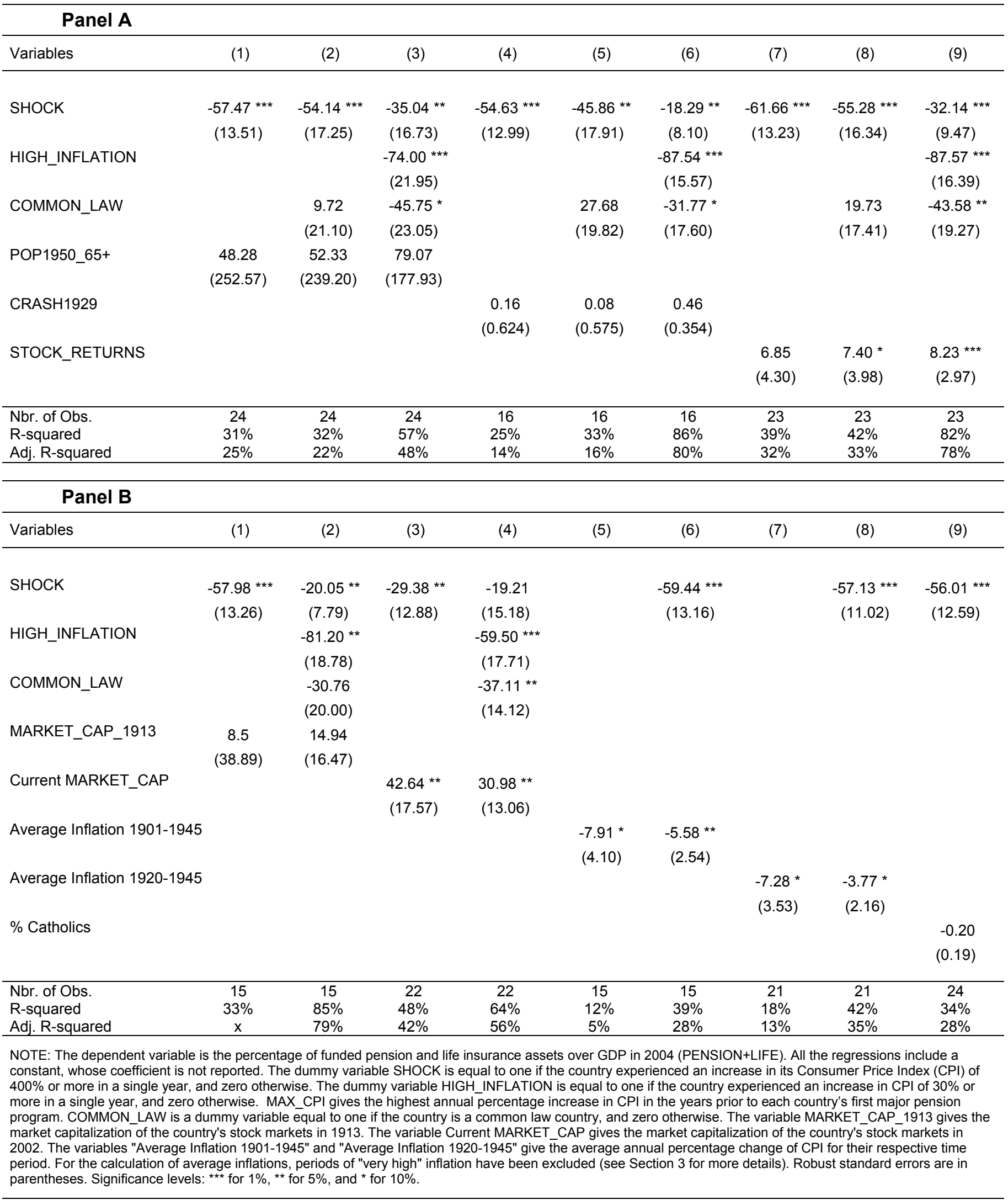


Table 6: Alternative Political Explanations of Pension Funding

\begin{tabular}{|c|c|c|c|c|c|c|}
\hline Variables & $(1)$ & $(2)$ & (3) & $(4)$ & $(5)$ & $(6)$ \\
\hline SHOCK & & $\begin{array}{c}-40.03^{* * *} \\
(9.82)\end{array}$ & $\begin{array}{c}-23.96 \text { *** } \\
(8.41)\end{array}$ & & $\begin{array}{c}-52.48^{* * *} \\
(14.84)\end{array}$ & $\begin{array}{c}-36.35 \text { ** } \\
(14.60)\end{array}$ \\
\hline HIGH_INFLATION & & & $\begin{array}{c}-42.72 \text { *** } \\
(13.69)\end{array}$ & & & $\begin{array}{l}-41.94 \text { * } \\
(22.42)\end{array}$ \\
\hline Income Inequality (Gini Coefficient) & $\begin{array}{l}-2.70 * * * \\
(0.953)\end{array}$ & $\begin{array}{l}-1.91 \text { ** } \\
(0.910)\end{array}$ & $\begin{array}{l}-0.983 \text { * } \\
(0.542)\end{array}$ & & & \\
\hline Majoritarian Electoral Rule Dummy & & & & $\begin{array}{l}38.32 \text { ** } \\
(15.07)\end{array}$ & $\begin{array}{c}21.74 \\
(17.45)\end{array}$ & $\begin{array}{c}4.33 \\
(18.77)\end{array}$ \\
\hline Nbr. of Obs. & 21 & 21 & 21 & 24 & 24 & 24 \\
\hline R-squared & $25 \%$ & $43 \%$ & $63 \%$ & $12 \%$ & $35 \%$ & $49 \%$ \\
\hline Adj. R-squared & $21 \%$ & $36 \%$ & $57 \%$ & $8 \%$ & $28 \%$ & $41 \%$ \\
\hline
\end{tabular}

NOTE: The dependent variable is the percentage of funded pension and life insurance assets over GDP in 2004 (PENSION+LIFE). All the regressions include a constant, whose coefficient is not reported. The dummy variable SHOCK is equal to one if the country experienced an increase in its Consumer Price Index (CPI) of $400 \%$ or more in a single year, and zero otherwise. The dummy variable HIGH_INFLATION is equal to one if the country experienced an increase in CPI of $30 \%$ or more in a single year, and zero otherwise. "Income Inequality" is measured as the Gini coefficient of income as provided by Forbes (2000) for the earliest time period available. The variable "Majoritarian Electoral Rule" is a dummy variable equal to one if electoral rule is based on majority, and zero otherwise (Tabellini et al, 2003). Robust standard errors are in parentheses. Significance levels: ${ }^{* \star *}$ for $1 \%$, ${ }^{* *}$ for $5 \%$, and ${ }^{*}$ for $10 \%$. 
Table 7: Effect of War Damage and Political System on Inflationary Shock

\begin{tabular}{|c|c|c|c|c|c|c|c|c|}
\hline Variables & $(1)$ & $(2)$ & (3) & (4) & $(5)$ & (6) & (7) & (8) \\
\hline War Destruction Variable $(0 / 3)$ & $\begin{array}{l}0.234 * * * \\
(0.077)\end{array}$ & $\begin{array}{l}0.190 * * \\
(0.088)\end{array}$ & $\begin{array}{l}0.269 * * \\
(0.109)\end{array}$ & $\begin{array}{l}0.194 * * \\
(0.089)\end{array}$ & $\begin{array}{l}0.280 * * \\
(0.119)\end{array}$ & & & \\
\hline Quality of Democracy & & $\begin{array}{l}-0.025 \\
(0.027)\end{array}$ & $\begin{array}{r}-0.009 \\
(0.028)\end{array}$ & & & & $\begin{array}{c}0.068 \\
(0.062)\end{array}$ & $\begin{array}{c}0.322 \\
(0.183)\end{array}$ \\
\hline $\begin{array}{l}\text { Quality of Democracy * War Destruction } \\
\text { (Interactive Term) }\end{array}$ & & & $\begin{array}{l}-0.012 \\
(0.016)\end{array}$ & & & & & \\
\hline Polity Variable & & & & $\begin{array}{l}-0.013 \\
(0.133)\end{array}$ & $\begin{array}{l}-0.006 \\
(0.015)\end{array}$ & & & \\
\hline $\begin{array}{l}\text { Polity Variable * War Destruction } \\
\text { (Interactive Term) }\end{array}$ & & & & & $\begin{array}{l}-0.006 \\
(0.009)\end{array}$ & & & \\
\hline Change in Population from 1914-1919, in \% & & & & & & $\begin{array}{l}-1.110 * * * \\
(0.159)\end{array}$ & $\begin{array}{l}-1.775^{* *} \\
(0.653)\end{array}$ & $\begin{array}{c}-1.280 * * * \\
(0.351)\end{array}$ \\
\hline $\begin{array}{l}\text { Change in Population from 1914-1919* } \\
\text { Quality of Democracy (Interactive Term) }\end{array}$ & & & & & & & & $\begin{array}{l}-0.287 \\
(0.178)\end{array}$ \\
\hline Nbr. of Obs. & 24 & 23 & 23 & 23 & 23 & 16 & 16 & 16 \\
\hline R-squared & $26 \%$ & $29 \%$ & $30 \%$ & $29 \%$ & $30 \%$ & $40 \%$ & $46 \%$ & $55 \%$ \\
\hline Adj. R-squared & $23 \%$ & $22 \%$ & $19 \%$ & $22 \%$ & $19 \%$ & $36 \%$ & $38 \%$ & $44 \%$ \\
\hline
\end{tabular}




\section{Appendix}

\section{Political choice over capital market orientation}

We sketch here a simple model drawn from Perotti and von Thadden (2006), which endogenizes political support for minority investor protection.

Suppose voters choose whether decisions made by firms will be dominated by dispersed shareholders or larger investors or banks. Each voter $i$ has human capital in equal measure, but a different endowment in financial capital, measured by the fraction $\theta_{\mathrm{i}}$ of total financial capital (s)he holds. They are risk averse with mean-variance preferences, and work for ex ante identical firms which earn iid random profits $\pi$. Each firm has shares and bank debt equal to B. Would a majority of investors prefers to grant corporate power to dispersed equity holders ${ }^{24}$

For simplicity, financial risk may be fully diversified, so that there is an optimal fully diversified portfolio $\mathrm{F}$ holding all securities (shares and bank loans). We posit the standard assumption that labor income risk cannot be hedged, so that the wage $\mathrm{W}$ is optimally set to be a senior claim. Actual labor income w equals Max [W, $\pi$. Thus each agent has expected income equal to its expected value of labor income plus his or her share of financial wealth, $\theta_{\mathrm{i}} \mathrm{F}$, and makes political choices so as to maximize

$\operatorname{Max} E(W)-1 / 2 A \operatorname{Var}(W)=\operatorname{Max} E \operatorname{Max}[W, \pi]+\theta_{i} E(F)-1 / 2 \operatorname{Var}(W)$

where $\mathrm{A}$ is the coefficient of absolute risk aversion and $\mathrm{E}(\mathrm{F})=\Sigma \min \left(\pi_{\mathrm{i}}-\mathrm{W}, 0\right)$ for all firms, and $\operatorname{Var}(\mathrm{W})=\operatorname{prob}(\mathrm{W}<\pi) \operatorname{Var}(\pi \mid \mathrm{W}<\pi)$.

The dominant investors choose whether firms should adopt a profitable but risky strategy R with return $\pi_{\mathrm{H}}$ and variance $\sigma_{\mathrm{H}}$ or a safer but less profitable strategy $\mathrm{S}$ with return $\pi_{\mathrm{L}}$ and variance $\sigma_{\mathrm{L}}$. Since financial risk is diversifiable, dispersed investors prefer the high risk strategy which however creates more labor income risk. The safer strategy is chosen only when control is given to large investor or banks, provided the claim $\mathrm{W}$ is not too high. Thus the median voter chooses minority investor protection by trading off more 
financial wealth (in proportion to $\theta_{\mathrm{i}}$ ) versus more labor income risk. Clearly, if the median voter is not wealthy enough, its choice will be for weak investor protection so as to block control by dispersed market investors.

The basic result is that in a democratic society with diffused financial holdings, a majority will grant strong minority equity protection and thus control to equity control, while in a society where wealth is concentrated among the very rich, the median class prefers weak investor protection (which leads to concentrated equity or bank control). Formally, support for minority investor protection will emerge when the financial stake held by the median voter $\theta_{\mathrm{M}}$ exceeds a threshold such that ${ }^{25}$

$\theta_{\mathrm{M}} \mathrm{E}\left(\pi_{\mathrm{R}}-\pi_{\mathrm{L}}-\mathrm{W}\right)<\mathrm{E} \operatorname{Max}\left[\mathrm{W}, \pi_{\mathrm{L}}\right]-\mathrm{E} \operatorname{Max}\left[\mathrm{W}, \pi_{\mathrm{R}}\right]+1 / 2 \mathrm{~A}\left\{\operatorname{Var}\left(\mathrm{W} \mid \pi_{\mathrm{R}}\right)-\operatorname{Var}\left(\mathrm{W} \mid \pi_{\mathrm{L}}\right)\right\}$

The model predicts lack of political support for investor protection, and thus capital market development, when the capital gain accruing to the median voter from the riskier strategy does not compensate enough for the utility loss caused by the higher associated risk for his labor income. ${ }^{26}$ Financial participation by the middle class turns out to be critical for political support for investor protection.

\footnotetext{
${ }^{24}$ Assigning control to concentrated owners induces a safe strategy since high control benefits are enjoyed only as long as the firm remains solvent.

${ }^{25}$ This threshold always exists under reasonable conditions on the distributions of $\pi_{\mathrm{R}}$ and $\pi_{\mathrm{L}}$; in particular, $\pi_{\mathrm{R}}$ should not stochastically dominate $\pi_{\mathrm{L}}$ (Perotti and von Thadden, 2006).

${ }^{26}$ In Perotti and von Thadden (2006), labor rents are also a political choice. Since more unequal societies support higher labor rents and thus more labor income risk, this reinforces the preference for less risk.
} 